\title{
DL-methionine supplementation of rice-and-bean diets affects gamma-glutamyltranspeptidase activity and glutathione content in livers of growing rats
}

\section{I.M.V. De-Oliveira, E. Fujimori, \\ V.G. Pereira and \\ V.D. De-Castro}

Laboratório de Nutrição, Departamento de Enfermagem em Saúde Coletiva, Escola de Enfermagem, Universidade de São Paulo, São Paulo, SP, Brasil

\section{Correspondence \\ I.M.V. De-O liveira \\ Departamento de Enfermagem em Saúde Coletiva \\ Escola de Enfermagem, USP \\ Av. Dr. Enéas C. Aguiar, 419 \\ 05403-000 São Paulo, SP \\ Brasil \\ Fax: + 55-11-3066-7662 \\ E-mail: imolise@ usp.br}

Research supported by FAPESP (No. 95/0543-4).

Received March 3, 1998 Accepted November 30, 1998

\section{Abstract}

Gamma-glutamyltranspeptidase (GGT-EC 2.3.2.2) activity and glutathione $(\mathrm{GSH})$ content were measured in livers of female weanling Wistar rats $(\mathrm{N}=5-18)$, submitted to rice-and-bean diets $(13$ and $6 \% \mathrm{~W} /$ w protein), both supplemented or not with DL-methionine ( 0.5 and $0.23 \mathrm{~g} / 100 \mathrm{~g}$ dry diet, respectively). After 28 days, the rats on the riceand-bean diets showed significantly higher levels (four times higher) of liver GGT activity and a concomitant $50 \%$ lower concentration of liver GSH in comparison with control groups feeding on casein. The addition of DL-methionine to rice-and-bean diets significantly increased the liver GSH content, which reached levels 50\% higher than those found in animals on casein diets. The increase in GSH was accompanied by a decrease in liver GGT activity, which did not reach levels as low as those observed in the control groups. No significant correlation could be established between GGT and GSH changes under the present experimental conditions. Linear correlation analysis only revealed that in animals submitted to unsupplemented rice-andbean diets GSH concentration was positively associated $(\mathrm{P}<0.05)$ with weight gain, food intake and food efficiency. GGT, however, was negatively correlated $(\mathrm{P}<0.05)$ with food intake only, and exclusively for supplemented rice-and-bean diets. The high levels of GGT activity observed in the present study for rats receiving a rice-and-bean mixture could be a result of the poor quality of these diets associated with their deficiency in sulfur amino acids. The results also suggest that diet supplementation with methionine could be important in the reduction of the deleterious effects of GSH depletion by restoring the intracellular concentration of this tripeptide.

\section{Key words}

- Liver gamma glutamyltranspeptidase

- Liver glutathione

- Protein deficiency

- Rice-and-bean diet

- Growing rats

- DL-methionine

supplementation 
Reduced glutathione (GSH; $\gamma$-glutamylcysteinylglycine) is the major nonprotein thiol constituent of cells and plays an important role in the intracellular protection against toxic compounds $(1,2)$. Of the three constituent amino acids of GSH, cysteine is the most limiting for GSH synthesis $(3,4)$. The most important source of cysteine is dietary intake, either directly as a constituent of dietary protein, or indirectly through conversion from methionine via the cystathionine pathway (35). As a result, methionine can function as a cysteine precursor and both methionine and cysteine may participate in drug metabolism as GSH precursors. Although the mechanism involved is not completely understood, the lack of a precursor is likely to contribute to a decreased tissue GSH concentration $(4,6)$. In rats on diets of varied protein content, plasma cysteine is the best indicator of liver GSH concentration (7). The protein status of the animals, therefore, has an influence on the regulation of GSH levels. In fact, the concentration of hepatic GSH is reduced in cases of protein-energy malnutrition (6-8), but malnourished rats are able to replenish GSH when sulfur amino acids or methyl donors are provided $(6,9)$.

Furthermore, the feeding of diets deficient in methionine and methyl donor compounds produces fatty livers (10) and increases hepatic gamma-glutamyltranspeptidase (GGT; EC 2.3.2.2) activity. In a previous study (de-Oliveira IMV and De-Angelis $\mathrm{RC}$, unpublished results), growing rats on legume-based diets (as bean or rice-andbean diets), which are known to be deficient in sulfur amino acids, showed a significant increase in the activity of this enzyme. GGT, which is a cell enzyme bound to the plasma membrane, catalyzes the transfer from the gamma-glutamyl moiety originating from GSH and other gamma-glutamyl compounds to a variety of amino acids and peptides (4); it is also the only enzyme able to degrade GSH (1), thus being involved in protein synthesis and amino acid transport, since it mo- bilizes cysteine from the liver GSH pool $(10,11)$. It has been suggested that GGT can confer resistance against free radical-induced toxicity related to GSH depletion on drugmetabolizing cells (12). Elevated activity of this enzyme has also been associated with conditions of protein-calorie deprivation (13).

In Brazil, where traditional rice-and-bean mixtures constitute the most important dietary source of protein for various strata of the population, protein-calorie malnutrition is currently considered to be a public health problem. In view of the response of GGT and GSH to protein-calorie malnutrition, it seemed interesting 1) to determine the effect of a diet deficient in sulfur amino acids based on a rice-and-bean mixture on both hepatic GGT activity and GSH content, 2) to determine if DL-methionine added to these diets would be effective in increasing hepatic GSH concentration, and 3) to determine the GSH to GGT relationship under the above conditions.

Female weanling Wistar rats initially weighing $41.7 \pm 3.7 \mathrm{~g}$ were obtained from the Central Animal House of the School of Medicine, University of São Paulo, and placed individually in suspended galvanized iron cages kept in a room with controlled temperature $\left(25^{\circ} \mathrm{C}\right)$ and humidity $(\sim 60 \%)$. Lights were on from 7:00 a.m. to 7:00 p.m. The rats were randomly assigned to six different treatment groups of 5 or more animals each. Each group was fed either a casein-based (13 and 6\% w/w protein) or a rice-and-bean-based (13 and $6 \% \mathrm{w} / \mathrm{w}$ protein) semi-purified diet supplemented or not with DL-methionine, and prepared following most of the recommendations of the American Institute of Nutrition for rodent diets. The composition of the casein-based diet was (in weight): $10 \%$ sucrose, $8 \%$ corn oil, $3.5 \%$ mineral mixture (14), $1.0 \%$ vitamin mixture (14), $1.0 \%$ cellulose and $76.5 \%$ cornstarch. The rice (Oryza sativa L. var. Agulhinha) and the beans (Phaseolus vulgaris L. var. Carioca) for the rice-and-bean diet were obtained commercially. The preparation of the rice-and-bean diet con- 
sisted of the following steps: soaking in water (2:1 and $4: 1 \mathrm{w} / \mathrm{v}$, respectively), cooking (20 and $180 \mathrm{~min}$, respectively), drying (for $12 \mathrm{~h}$ in a ventilated stove), grinding $(0.297 \mathrm{~mm})$, and mixing $(1: 1 \mathrm{w} / \mathrm{w})$. The resulting rice-and-bean mixture was analyzed for nitrogen by the micro-Kjeldahl method and its protein content was estimated using the factor 6.25 . According to their content of fat, minerals and vitamins, the 13 and $6 \%$ rice-and-bean mixtures were supplemented with corn oil (4 and $6 \%$, respectively), a mineral mix (1.5 and $2.2 \%$, respectively), and a vitamin mix $(0.5$ and $0.8 \%$, respectively). Since the casein $(77.6 \%$ protein) and the rice-and-bean mixture $(14.4 \%$ protein) contain 2.2 and $0.2 \mathrm{~g}$ methionine/ $100 \mathrm{~g}$, respectively, both protein sources were adjusted to a common level of $0.7 \%$ methionine content by the addition of DL-methionine ( 0.5 and $0.23 \mathrm{~g} / 100 \mathrm{~g}$ dry diet, respectively). The two levels of protein content (13 and 6\%) were obtained by adding cornstarch and sucrose. All diets were practically isocaloric (4.1 to $4.3 \mathrm{cal} / \mathrm{g}$ diet). All rats had free access to food and water for 28 days. Weight gain and food intake were recorded on alternate mornings between 9:00 and 11:00 a.m.

At the end of the 28-day experimental period the animals were sacrificed by cardiac puncture under ether anesthesia. Livers were rapidly removed and weighed and fragments were immediately used for GGT and GSH analyses; the remaining tissue was frozen and stored at $-30^{\circ} \mathrm{C}$ for subsequent analysis. The liver samples were homogenized in a medium containing $1.21 \mathrm{M}$ mannitol, 0.07 $\mathrm{M}$ sucrose, and $0.1 \mathrm{mM}$ EDTA, adjusted to $\mathrm{pH}$ 7.4. Aliquots of this homogenate were used for the determination of GGT activity (15). The same volume of cold $1.2 \mathrm{~N}$ perchloric acid, containing $2 \mathrm{mM}$ EDTA, was added to this homogenate, and the mixture was centrifuged $(15,000 \mathrm{~g}$ for $10 \mathrm{~min})$ for the separation of the "acid supernatant". All procedures were performed at $4^{\circ} \mathrm{C}$. The "acid supernatant" was used to estimate reduced glutathione (16). Protein content was determined by the method of Lowry et al. (16). All data are reported as means $\pm \mathrm{SD}$ and were analyzed either by ANOVA or by the Kruskal-Wallis test (the latter, when Bartlett's test showed no variance homogeneity). Differences were accepted as significant at $\mathrm{P}<0.05$. Pearson correlation coefficient for continuous variables was calculated.

At the end of the experiment, the rats ingesting the 13 and $6 \%$ rice-and-bean diets had a 62.6 and $84.7 \%$ lower body weight gain than the rats receiving the 13 and $6 \%$ casein control diets (Table 1).

Table 1 - Effect of dietary protein on biological parameters of rats during growth (22-50 days of age).

Data are reported as means \pm SD $(\mathrm{N}=5$-18). In any one column, the values of the means marked with different superscripts are significantly different $(P<0.05$, ANOVA test for two groups). Food efficiency $=$ weight gain/food intake; DL-met $=$ DL-methionime.

\begin{tabular}{|c|c|c|c|c|c|}
\hline Diets & $\begin{array}{l}\text { Initial body } \\
\text { weight }(g)\end{array}$ & $\begin{array}{l}\text { Weight gain } \\
\text { (g) }\end{array}$ & $\begin{array}{l}\text { Food intake } \\
\text { (g/day) }\end{array}$ & $\begin{array}{l}\text { Protein intake } \\
\text { (g/day) }\end{array}$ & $\begin{array}{c}\text { Food } \\
\text { efficiency }\end{array}$ \\
\hline \multicolumn{6}{|l|}{ 13\% Protein } \\
\hline Casein & $42.39 \pm 3.84^{a}$ & $161.08 \pm 20.01^{a}$ & $15.06 \pm 1.08^{a}$ & $1.96 \pm 0.14^{a}$ & $0.38 \pm 0.05^{a}$ \\
\hline Rice-bean & $41.22 \pm 3.98^{a}$ & $60.33 \pm 3.95^{b}$ & $10.25 \pm 0.72^{b}$ & $1.33 \pm 0.10^{b}$ & $0.21 \pm 0.01^{b}$ \\
\hline Rice-bean + DL-met & $42.32 \pm 2.90^{a}$ & $116.54 \pm 11.01^{c}$ & $12.48 \pm 1.02^{\mathrm{c}}$ & $1.62 \pm 0.13^{c}$ & $0.33 \pm 0.01^{c}$ \\
\hline \multicolumn{6}{|l|}{ 6\% Protein } \\
\hline Casein & $41.32 \pm 3.72^{a}$ & $120.60 \pm 6.60^{c}$ & $14.40 \pm 1.04^{a}$ & $0.86 \pm 0.06^{d}$ & $0.30 \pm 0.01^{d}$ \\
\hline Rice-bean & $42.00 \pm 3.39 a$ & $18.42 \pm 3.79^{d}$ & $6.85 \pm 0.81^{d}$ & $0.41 \pm 0.05^{e}$ & $0.10 \pm 0.02^{e}$ \\
\hline Rice-bean + DL-met & $41.03 \pm 4.41^{a}$ & $47.00 \pm 8.28^{e}$ & $9.70 \pm 1.08^{b}$ & $0.58 \pm 0.07^{f}$ & $0.17 \pm 0.02^{f}$ \\
\hline
\end{tabular}


A reduction of dietary protein from 13 to $6 \%$ reduced by $25.1 \%$ the body weight gain of rats feeding on casein and by $69.5 \%$ the weight gain of rats feeding on rice and beans. These body weight alterations paralleled a reduction of food intake of $4.4 \%$ for control rats and of $33.2 \%$ for rats fed rice and beans. The reduction in protein ingestion was more pronounced in animals submitted to riceand-bean diets than in animals submitted to casein diets (69.2 vs 56.1\%). The food efficiency reflected these results, being significantly lower, both due to protein restriction and to rice-and-bean consumption, which clearly showed the qualitative inferiority of rice-and-bean protein.

The addition of methionine to the riceand-bean diets reduced these differences. At both levels of dietary protein, a significant increase in food intake, protein intake, and weight gain was observed in rats on the diets supplemented with methionine as compared to rats on unsupplemented diets (Table 1). Supplementation also significantly increased food efficiency. However, the ingestion of food, the food efficiency, and the body weight gain were consistently lower than the same parameters observed in rats submitted to the casein diets (of the same protein content).

The effects of protein content and methi-

Table 2 - Effect of protein restriction on GGT activity, GSH concentration and protein concentration in the liver of rats during growth (22-50 days of age).

Data are reported as means \pm SD ( $N=5-18)$. In any one column, the values of the means marked with different superscripts are significantly different $(P<0.05$, ANOVA test for two groups). $U=\mu \mathrm{mol}$ of $\mathrm{p}$-nitroaniline released $/ \mathrm{min}$, at $37^{\circ} \mathrm{C}$; DL-met $=\mathrm{DL}$ methionine.

\begin{tabular}{llll}
\hline Diets & \multicolumn{1}{c}{$\begin{array}{c}\text { GGT } \\
\text { (U/g protein) }\end{array}$} & $\begin{array}{c}\text { GSH ( } \mu \text { mol/g } \\
\text { wet weight) }\end{array}$ & $\begin{array}{c}\text { Protein }(\mathrm{mg} / \mathrm{g} \\
\text { wet weight) }\end{array}$ \\
\hline $\begin{array}{l}\text { 13\% Protein } \\
\text { Casein }\end{array}$ & $0.40 \pm 0.25^{\mathrm{a}}$ & $3.66 \pm 1.17^{\mathrm{a}}$ & $245.36 \pm 23.61^{\mathrm{ab}}$ \\
$\quad$ Rice-bean & $1.56 \pm 0.67^{\mathrm{bd}}$ & $1.74 \pm 0.15^{\mathrm{b}}$ & $280.93 \pm 47.46^{\mathrm{a}}$ \\
Rice-bean + DL-met & $0.79 \pm 0.16^{\mathrm{c}}$ & $5.51 \pm 0.27^{\mathrm{c}}$ & $226.96 \pm 49.73^{\mathrm{ab}}$ \\
& & & \\
6\% Protein & & & \\
$\quad$ Casein & $0.96 \pm 0.84^{\mathrm{cd}}$ & $3.48 \pm 0.34^{\mathrm{a}}$ & $276.48 \pm 73.65^{\mathrm{ab}}$ \\
$\quad$ Rice-bean & $2.17 \pm 0.74^{\mathrm{b}}$ & $1.13 \pm 0.11^{\mathrm{d}}$ & $252.18 \pm 29.38^{\mathrm{ab}}$ \\
$\quad$ Rice-bean + DL-met & $1.85 \pm 1.23^{\mathrm{bc}}$ & $5.19 \pm 0.54^{\mathrm{c}}$ & $222.13 \pm 35.63^{\mathrm{b}}$ \\
& & &
\end{tabular}

onine supplementation on hepatic GGT activity and GSH concentration are shown in Table 2. Protein depletion significantly decreased the liver GSH concentration by $35 \%$, for rats on the rice-and-bean mixture. In the animals submitted to the supplemented riceand-bean diets, the GSH concentration significantly increased and exceeded the level found in animals on casein diets. No significant effects of protein level were observed on the increase of GSH resulting from the addition of sulfur amino acids.

When amino acids containing sulfur are limited in a diet, there is an expected reduction in hepatic GSH levels $(5,6,8)$. However, when sulfur amino acids or methyl donors are supplied, malnourished rats are able to replenish GSH to higher levels than those found in control animals $(6,8,9)$. The present data agree with the cited studies and corroborate the relationship between increases in hepatic GSH concentration and DL-methionine supplementation under conditions of protein deficiency. This fact could be taken as an indication of an abnormal homeostatic regulation of liver GSH in proteincalorie restriction under conditions of cysteine availability. One possible mechanism for this loss of the homeostatic control of hepatic GSH concentration could be a disruption of the hormonal regulation since GSH synthesis is insensitive to regulation by c-AMP in rats with protein-energy malnutrition (8). Other studies have suggested that protein-malnourished rats may retain their capacity of synthesizing GSH when an adequate substrate is provided, which could be regarded as a mechanism to preserve cysteine for use when its availability is low (5). Under conditions of low cysteine availability, its utilization is favored in GSH synthesis, although sulfate and taurine also increase substantially on a molar basis with increasing cysteine concentration (5). This fact emphasizes the essential role played by $\mathrm{GSH}$ as a metabolite that functions as a vehicle for cysteine delivery. Previous re- 
ports $(9,10,18)$ have provided some evidence that liver GSH can function as an endogenous cysteine reservoir during starvation and can provide cysteine for protein synthesis during periods of inadequate cysteine intake $(9,18)$. The breakdown of GSH occurs extracellularly and is catalyzed by GGT (10), which is bound to the external surface of cell membranes (4).

In the present study, liver GGT activity accompanied alterations of liver GSH content. Enzyme activity increased under protein restrictive conditions, with the most significant increases occurring in rats on riceand-bean diets. The influence of protein content, however, was significant $(\mathrm{P}<0.05)$ only for casein-fed rats. Apart from that, protein quality significantly affected hepatic GGT activity, which was higher for rats submitted to rice-and-bean diets than for those on casein diets. Supplementation with DL-methionine reduced GGT activity, especially in the rats submitted to the $13 \%$ protein $\operatorname{diet}(\mathrm{P}<0.05)$. Thus, the high GGT activity observed in the present study, mainly in rats on rice-andbean diets, could be a consequence of the poor quality of these diets and could be associated with their deficiency in sulfur amino acids. The marked induction of liver GGT observed here for rats fed rice-andbean diets could be justified in the same fashion as the reduction observed in GSH levels. The hepatic GGT activity is also dietdependent and responds both to protein (19) and to sulfur amino acid deprivation (deOliveira IMV and De-Angelis RC, unpublished results). This may justify its elevation in the serum of malnourished children and women, as well as its return to normal activity after nutritional recovery (13). Even if the results suggest the existence of a relationship between GGT and GSH, no significant correlation could be established between them under the present experimental conditions. For the rats submitted to unsupplemented rice-and-bean diets, linear correlation analysis revealed that GSH concentra- tion was positively associated with weight gain, food intake, and food efficiency ( $r=$ $0.61 ; \mathrm{CL}=0.27,0.82 ; \mathrm{P}<0.0001)$. GGT, however, was negatively correlated with food intake only $(r=-0.67$; CL $=-0.91,-0.12$; $\mathrm{P}<0.0001$ ), and exclusively for the supplemented rice-and-bean diet. Even if this topic has not been pursued in this study, previous data (de-Oliveira IMV, Fujimori E, Pereira VG and Lima AR, unpublished results) have established a significant correlation between these two parameters in rats submitted to chronic protein malnutrition.

In addition, the fact that rice-and-bean diets can cause the depletion of hepatic GSH might suggest that such diets predispose the liver to injuries caused by ingested drugs or other toxins that would normally be cleared by the adequate GSH levels found in normal hepatocytes. A recent review (11) on GSH deficiency in human diseases has provided evidence that severe GSH deficiency might lead to marked mitochondrial damage associated with ethanol-induced injuries in a number of tissues. In such cases, mitochondrial damage seems to be mediated by endogenous production of hydrogen peroxide and other reactive oxygen species produced during normal aerobic metabolism. The authors (11) considered that depleted levels of mitochondrial GSH are inadequate to prevent injury in this situation. Given that GSH levels are sensitive to protein nutritional status, one is justified in expecting a decreased capacity for detoxification and differing responses to the stress associated with infections and inflammation resulting either from malnutrition or from the consumption of rice and beans. Jahoor (20), in a study about the mechanisms responsible for depletion of systemic GSH in nutritional deprivation and/or in infective and inflammatory conditions, concluded that the biosynthetic supply of GSH is insufficient to withstand an inflammatory challenge in protein-deficient animals.

In conclusion, diet supplementation with methionine or other sulfur amino acids con- 
taining protein could be important in order to overcome the GSH depletion and to decrease the susceptibility to oxidative stress induced by diets based on rice and beans.

\section{Acknowledgments}

The authors are grateful to "Roche do
Brasil" for the donation of a vitamin mixture. The authors would also like to thank the staff of the Department of Food Science and Experimental Nutrition of the Faculty of Pharmaceutical Sciences, Department of Protozoology of the Institute of Tropical Medicine, and the Cafeteria of the School of Nursing for their help and support.

\section{References}

1. Anderson ME (1996). Glutathione. In: Punchard NA \& Kelly FJ (Editors), Free Radicals: A Practical Approach. IRL Press, Oxford.

2. Comporti M, Maellaro E, Del Bello B \& Casini AF (1991). Glutathione depletion: its effect on other antioxidant systems and hepatocellular damage. Xenobiotica, 21: 1067-1076.

3. Beatty PW \& Reed DJ (1980). Involvement of the cystathionine pathway in the biosynthesis of glutathione by isolated rat hepatocytes. Archives of Biochemistry and Biophysics, 204: 80-87.

4. Meister A (1991). Glutathione deficiency produced by inhibition of its synthesis, and its reversal applications in research and therapy. Pharmacology and Therapeutics, 51: 155-194.

5. Stipanuk MH (1992). Cysteine concentration regulates cysteine metabolism to glutathione, sulfate and taurine in rat hepatocytes. J oumal of Nutrition, 122: 420-427.

6. Bauman P, Smith TK \& Bray TM (1988). The effect of dietary protein and sulfur amino acids on hepatic glutathione concentration and glutathione dependent enzyme activity in the rat. Canadian J ournal of Physiology and Pharmacology, 66: 1048-1052.

7. Hum S, Koski KG \& Hoffer LJ (1992). Varied protein intake alters glutathione me- tabolism in rats. J oumal of Nutrition, 122: 2010-2018

8. Goss PM, Bray TM \& Nagy LE (1994). Regulation of hepatocyte glutathione by amino acid precursors and CAMP in protein-energy malnourished rats. J oumal of Nutrition, 124: 323-330.

9. Cho ES, J ohnson N \& Snider BCF (1984). Tissue glutathione as a cyst(e)ine reservoir during cystine depletion in growing rats. J oumal of Nutrition, 114: 1853-1862.

10. Speisky $H$, Shackel $N$, Varghese $G$, Wade D \& Israel Y (1990). Role of hepatic $\gamma$ glutamyltransferase in the degradation of circulating glutathione: Studies in the intact guinea pig perfused liver. Hepatology, 11: 843-849.

11. White AC, Thannickal VJ \& Fanburg BL (1994). Glutathione deficiency in human disease. J ournal of Nutritional Biochemistry, 5: 218-226.

12. Hanigan M \& Pitot H (1985). Gammaglutamyltranspeptidase - its role in hepatocarcinogenesis. Carcinogenesis, 6: 165172.

13. Antener I, Givel F, Mauron J \& Verwilghen AM (1980). Measurement of serum isoenzymes of $\gamma$-glutamyl-transpeptidase in malnutrition. Acta Paediatrica, 33: 9-15.

14. Reeves PG, Nielsen FH \& Fahey J r GG (1993). AIN-93 Purified diets for laboratory rodents: Final report of the American
Institute of Nutrition Ad Hoc Writing Committee on the Reformulation of AIN-76A Rodent diet. J ournal of Nutrition, 123: 1942.

15. Persijn J P (1971). Colorimetric assay for $\gamma$ glutamyl transpeptidase. Clinica Chimica Acta, 35: 239-240.

16. Saville B (1958). A scheme for the colorimetric determination of microgram amounts of thiols. Analyst, 83: 670-671.

17. Lowry $\mathrm{OH}$, Rosebrough $\mathrm{NJ}$, Farr $\mathrm{AL} \&$ Randall RJ (1951). Protein measurement with Folin phenol reagent. J ournal of Biological Chemistry, 19: 266-275.

18. Higashi T, Tateishi $N$, Naruse $A \&$ Sakamoto Y (1977). A novel physiological role of liver glutathione as resenvoir of Lcysteine. J ournal of Biochemistry, 82: 117-124.

19. Oliveira IMV \& De Angelis RC (1996). Differential effects of protein restriction gammaglutamyltranspeptidase (EC 2.3.2.2) activity in young and mature rats. Brazilian J ournal of Medical and Biological Research, 29: 213-217.

20. J ahoor $F$ (1995). Protein-deficient pigs cannot maintain reduced glutathione homeostasis when subjected to the stress of inflammation. J oumal of Nutrition, 125: 1462-1472. 